\title{
EDUCATING CORPORATE SOCIAL RESPONSIBILITY: LESSON LEARNED FROM THE MARKET
}

\author{
Eko Budi Santoso \\ Universitas Ciputra, INDONESIA, esantoso@ciputra.ac.id
}

\begin{abstract}
Corporate social responsibility disclosure becomes one of the popular topics in accounting education curricula as non-financial information for supporting decision making. Conceptually, corporate social responsibility disclosure is a reflection of company ethical behavior in their business practice. Its simplicity dan flexibility in the content reporting compare to complex and rigid information in financial statements start to make it more preferable when analyzing the fundamentals of the company. Evidence from the market shows that companies enjoy financial benefits by actively disclosing their corporate social responsibility. However, there are also cases where companies active in disclosing their social responsibility activities and gain predicate as socially responsible companies also involve in accounting scandals. These facts reveal that corporate social responsibility disclosure can also be used as a strategy to disguise corporate financial misconduct by using naturalistic fallacy in society. Corporate social responsibility has evolved not only to be limited to business ethics but has become part of a company's strategy and can even become a misleading strategy. Educating both conceptual and market-based lessons will give a broader but cautions perspective when analyzing a company's information. Using several Indonesian companies as case study, this paper provides evidence that non-financial information should be complementary rather than a substitution for the financial information, thus supporting the development of integrative reporting as a solution to get a comprehensive outlook of the company.
\end{abstract}

Keywords: Accounting education, corporate social responsibility, business ethics, business strategy, accounting fraud, naturalistic fallacy.

\section{INTRODUCTION}

Corporate social responsibility is a growing issue in the business world, along with the growing awareness that social responsibility is an integral part of business practice. Social responsibility has also transformed into a strategic issue for companies (Moura-Leite \& Padgett, 2011; Grougiou et al., 2016). McKinsey (2010) survey found that $76 \%$ of managers believe that corporate social responsibility has a positive effect on longterm company value and $55 \%$ of managers agree that corporate social responsibility helps to build a company's reputation. From the stakeholder perspective, corporate social responsibility also acts as an important role for stakeholders to assess and interact with the company (Maden et al., 2012; Arli \& Tjiptono, 2014). These factors encourage companies to actively undertake and discloses their social responsibility 
practices.

The trend of corporate social responsibility disclosure is interesting to be observed further. Social responsibility disclosure is still relatively new and is still looking for the ideal form. Governments and international institutions have issued regulations on corporate social responsibility disclosure. However, there is still no standard that regulates the components and mechanisms to disclose corporate social responsibility activity. The inadequacy of these standards results in the absence of a clear assurance mechanism in social responsibility disclosure completed by companies. Besides, developing countries still have weak law enforcement on corporate social responsibility practices (Muttakin et al. 2015). With these limitations, companies still persistently perform and disclose their social responsibility and try to obtain a title as companies that behave ethically by actively carrying out corporate social responsibility practices.

Another interesting thing about the practice of corporate social responsibility is the occurrence of paradox that discovers companies with a predicate of being active in practicing social responsibility are also companies that have been proven to committed financial fraud. This shows that companies that actively carry out social responsibility cannot necessarily be called companies that behave ethically. Thus, it is necessary to analyze the motivations that underlie the company's decision to disclose corporate social responsibility.

\section{CONCEPT \& PARADOX IN CORPORATE SOCIAL RESPONSIBILITY PRACTICES}

The concept of social responsibility is formally introduced Howard Rothmann Bowen in 1953 in his book titled Social Responsibilities of the Businessman stating that companies must pay attention to ethics in doing business to obtain superior long-term performance. Bowen, who then considered as the "Father of Corporate Social Responsibility" defines social responsibility as follow:

It refers to the obligations of businessman to pursue those policies, to make those decisions, or to follow those lines of action which are desirable in terms of the objectives and value of our society (Bowen, 1953).

The definition is considered as the beginning of the development of social responsibility, which is then followed by several definitions that are widely accepted, namely:

The Social responsibility of business encompasses the economic, legal, ethical, and discretionary expectations that society has of organization at a given point in time (Carroll, 1997).

Corporate Social Responsibility is the continuing commitment by business to behave ethically and contribute to economic development while improving the quality of life of the workforce and their families as well as of the local community and society at large (World Business Council for Sustainable Development, 2000).

According to the definitions above, it can be concluded that social responsibility is part of the companies' ethical behavior in the companies' ongoing commitment to operate and contribute to the community's economic development. In the early 1980s, the development of social responsibility leads to a concept of the triple bottom line (people, planet, profit) found by Joel Elkington. This concept states that to seek profit, companies should contribute to the social (people) and the environment (planet). In 2014, Ayman Sawaf introduced the fourth bottom line concept by incorporating the element of purpose. Thornton (2008) states that companies that adopt social responsibility principles believe that by operating ethically and responsibly, they will have a greater chance of success. This aspect encourages companies to be active in performing social responsibility.

Stakeholders also have the drive to conduct corporate social responsibility. The Indonesian government, through Law no. 40 of 2007 concerning Limited Liability Companies has requires disclosure on the implementation of social and environmental responsibility as one of the components in the annual report. This is followed by the Bapepam and LK KEP-431/BL/2012 regulations concerning Submission of Annual Report of Issuers or Public Companies which also requires similar thing for go-public companies, even though they have not regulated with detailed components and disclosure mechanisms. However, even when there are regulations that require companies to disclose their social responsibility, the absence of standards, a clear reporting and assurance mechanism, as well as strong law enforcement, lead to a vulnerability where social responsibility activity is misused by opportunistic managers. The reference that is often used in corporate social responsibility disclosure is the guidelines issued by Global Reporting Initiative (GRI) with the latest version called GRI-Standard. However, the reference is still in the form of guidelines that gives companies the flexibility to disclose their social responsibility. Mahadeo et al. (2011) stated that voluntary disclosure and the absence of standardized disclosure provides managers the flexibility to disclose information about corporate social responsibility. As result, corporate social responsibility disclosure has developed into several forms, namely as part of an annual report or reported separately which is also called 
as sustainability report. During its development, the concept of integrated reporting was pioneered by IFAC and GRI, two important organizations in the field of fields of accounting and social responsibility. On one hand, it shows the diversity of reporting models due to the absence of the standard, but on the other hand, it shows that there is a high level of concern for corporate social responsibility disclosure.

A strong drive also comes from consumers who perceive that corporate social responsibility is important (Arli \& Tjiptono, 2014). People have begun to have the tendency to use products produced by companies that are categorized as companies that actively doing social responsibility. This will have an impact on the company's profit through increased sales. Research conducted by Orlitzky et al., (2003), Blazovich \& Smith (2010), Lev et al. (2010), Harjoto \& Jo (2011), and Wang (2011) found that socially responsible activities have a positive effect on companies' performance. The awareness for social responsibility is also manifested by awards given to companies that act in conducting social responsibility practices. Companies that receive the awards are categorized as companies with a high level of social responsibility and is perceived as companies who have ethical business practices. These conditions motivate companies to compete in carrying out and disclosing their social responsibility. Holder-Webb et al. (2009) stated that companies should not only conduct social responsibility but also provide information about the corporate social responsibility activities to their stakeholders. Companies strive to widely publish their social responsibility activities to the public and are then labeled as a company that is actively involved in social responsibility activities. Stakeholders perceived companies that actively carry out social responsibility as companies that acts ethically in running their business.

However, some companies actively conduct social responsibility and are involved in financial scandals that create detrimental to several parties. For example, Enron, before the accounting scandal was exposed, was known as a company that is active in conducting social responsibility activities. In fact, in 1988, Enron receives a prestigious award, namely Climate Protection Award which was held by The United States Environmental Protection Agency, an environmental protection agency formed by the American government. In the same year, Enron committed a fraud which was revealed in 2001. On one hand, Enron actively carried out its social responsibly and on the other hand, it manipulated its financial statement. A similar case was found in Xerox, where for decades, they are famous for their social service programs involving its employees. From its effort, Xerox was awarded as the winner of World's Most Ethical Companies and is ranked $7^{\text {th }}$ in the list of 100 Best Corporate Citizen. But on the other hand, Xerox also committed a fraudulent scandal in its financial reporting by recognizing upfront income as the revenue and falsely classifies its business leases with a total fraudulent of 1.5 billion dollars. In Indonesia, at the least, 2 companies actively conduct social responsibility and receive awards, but at the same time committed fraud in taxation. The first company is PT. Asian Agri received social responsibility awards as the best community program from Pinnacle Group International and a gold medal in Indonesia CSR Awards (ICA) organized by the Corporate Forum for Community Development (CFCD) and the Coordinating Ministry for Human Development and Culture. However, PT Asian Agri was found to be involved in tax evasion of 1.25 trillion rupiah. The second company is PT. Kaltim Prima Coal which receives an international award in social responsibility by Global Green Future Awards and on multiple occasions has been awarded as one of the winners of the Indonesia Sustainability Reporting Awards (ISRA) organized by National Center for Sustainability Reporting as well as the ICA award. Like PT. Asian Agri, PT. Kaltim Prima Coal is also involved in a tax evasion scandal. This indicates that companies that are actively conducted social responsibility do not guarantee that the company its ethical behavior its business practices. Another case also happened to one of the biggest go public BUMNs in Indonesia, PT. Garuda Indonesia Tbk was involved in a fraudulent accounting scandal in recognizing its revenue. Garuda Indonesia is known to be active in carrying out social responsibility and has received awards in CSR, including a gold rank from Asia Sustainability Reporting Rating.

\section{PERSPECTIVE ON CORPORATE SOCIAL RESPONSIBILITY}

The reality of the massive social responsibility disclosure and paradox that have happened can be understood by looking at the perspectives that underlie companies in conducting their social responsibility activities. Two main perspectives motivate companies to actively disclose their social responsibility practices, which are instrumental and ethical. This section will discuss the philosophy and theory that underlies each perspective.

\subsection{Instrumental Perspective}

This perspective focuses on obtaining economic goals through social responsibility activities. The company places social responsibility as the company's instrument to gets financial benefits. The company will conduct and disclose social responsibility only if the activities will help the company to create a good image in the 
eyes of the stakeholder, which in turn will increase the company profits. In other words, social responsibility activities are conducted to be the company's instrument to create an image, so that it affects the company's profits. The company's image is not only used to influence stakeholders' perspectives about the company's image but also used to cover up frauds by the company. Companies take advantage of the assumption that companies who actively conduct social responsibility mean that the companies have behaved ethically in carrying out their business activities. This assumption may lead companies to commit in financial fraud and distract stakeholders by actively carrying out corporate social responsibility activities. Hemmingway \& Halagan (2004) stated that companies carry out social responsibility activities as a stool to cover up the impact of corporate fraud.

In addition, corporate social responsibility practices can also be used to neutralized or restore stakeholder confidence in the company's stigma. Ling \& Sultana (2013) used a sample of companies in Singapore found that companies with high stock volatility tend to disclose more social responsibility, especially in the fields of environment, energy, human resources, products, and consumers. This was done to give a positive image and maintain its stakeholders' trust. Research by Grougiou et al. (2016) shows that corporate social responsibility disclosure in companies that are sensitive to ethical issues is an integral part of the company's strategy to divert stakeholder's attention on the company's activities that are considered as controversial, reduce the consequences of the stigma, and neutralize the impact of litigation faced by the company. From the taxation perspective, Preus (2010) found that companies that have active tax avoidance activities by moving their head office locations to tax heaven countries claimed that the companies are conducting social responsibility activities. Furthermore, Fritzche (1991) stated that a company's ethical activities can act as window dressing when they are associated with self-interest and organizational egoism.

Several theories influence this perspective. The first theory is Shareholder Theory proposed by Milton Friedman in 1962 which stated that the only responsibility a company has is to use resources and engage in activities designed to increase profits (Friedman, 2002). The activities to increase their profits is aiming to improve the shareholders' welfare. Corporate social responsibility that does not positively affect the company's profits is considered as activities that are detrimental to the company, even when the activities can bring benefits to the stakeholders. This results in companies that only focus on corporate social activities that have a short-term and monumental (physical) nature so that they can immediately affect stakeholder's perspectives and their effect on profits is immediately visible. The second theory is resource-based view (RBV) theory (Wernerfelt, 1984; Barney, 1991) which stated that companies should adjust their internal capabilities to match the external condition needed for the company to achieve their goals. The companies' abilities to manage their resources and capabilities will lead to competitive advantages. Specifically, corporate social responsibility is categorized as the company's marketing strategy. Corporate social responsibility activities and disclosure are aimed to contribute to the company's marketing and sales performance. Studies by Juscius \& Kondratyuk (2012) and Tanjaya \& Santoso (2016) found that corporate social responsibility is a marketing tool that can increase the companies' performance. This shows that social responsibility is an instrument to gain bigger profits for the company. The third theory is Signaling theory (Spence, 1973; Ross 1977) which stated that there is information asymmetry in the market and companies with good performance tend to provide voluntary disclosure to the market so that the information can differentiate the company from other companies, which then will affect stakeholder perception towards company's performance. Social responsibility is still a voluntary disclosure, even though there are regulations that require a company to provide the disclosure, however, there is no standard and clear law enforcement, which makes the act of disclosure a voluntary nature. Companies conduct social responsibility to give a signal to the market that the company is active in carrying out its social responsibility and is hoped to affect the stakeholders' perceptions of the company, which then affect the company's performance. Based on these three theories, companies are using corporate social responsibility as an instrument to gain profits.

If drawn further, the instrumental perspective is related to several philosophies, which are Ethical egoism and Yangism. Ethical egoism was developed by Henry Sidgwick (1838-1900) who stated that every individual has a moral obligation to themselves and they will act in accordance with their respective interest. Thus, every action whose consequence is to bring benefits to the party is called an ethical action. Ethical egoism sees that individuals are not obligated to help the needs of others, unless if it benefits the helper. This philosophy is in line with an ancient philosophy of Yangism which was popularized by Yang Zhu (440-360 $\mathrm{BC}$ ) where its principle is called 'Wong Wei' or everything is for me. One of the famous expressions about Yang Zhu, which is raised by philosopher Mengzi is "What Yang Zhu does is for himself. If pulling a strand of hair would benefit the world, he would not do it." 


\subsection{Ethical Perspective}

The ethical perspective focuses on carrying out corporate social responsibility as a manifestation of the company's ethical behavior. From this perspective, the company will undertake social responsibility as the right thing to reach the civilized society because it reflects the company's true ethical behavior. In this perspective, social responsibility activities and disclosure is a form of the company's identity that holds ethical values in conducting its business. This also means that ethical behavior does not only reflects on their social responsibility aspect but also on all aspects of the company, including their financial aspect. Ethical behavior in financial reporting is manifested by the company's action in suppressing profit management practices because the actions are considered as violating ethical values. companies that operate with ethical principles will behave ethically by actively undertaking corporate social responsibility and reducing profit management activities. Kim et al. (2012) and Hong \& Andersen (2010) studies found that companies that are actively involved in social responsibility activities will have better quality financial reporting as indicated by higher accrual quality and lower profits earning management-based activities. Another study by Scholtens \& Kang (2012) on companies in 10 Asian countries found that corporate social responsibility activities negatively affect earnings management. Companies that actively conduct social responsibility as an embodiment of corporate value will have a more holistic and targeted program because their focus is to perform in ethical manners and not only to create an image to create bigger profit. The focus of social responsibility program should be projected for a long-term period to guarantee its sustainability.

The theory that underlies ethical perspective is stakeholder theory and integrative contract social theory. Stakeholder theory is developed by Freeman (1984) and it states that companies not only have responsibilities to their shareholders as owners of the company, but also to other parties who have certain claims of the companies, such as the suppliers, customers, employees, communities, and the government. Freeman stated that without the support from stakeholders, the company will not operate. In the stakeholder theory, normatively, a company must assume that all stakeholders are the same. Companies cannot emphasize social responsibility to certain parties. Such bias is categorized as unwise or unethical. Companies that run based on the stakeholder theory do not only maximize shareholder welfare at the expense of the stakeholders. The company will not exploit certain stakeholders and use social responsibility as a tool to cover up these activities. A company is considered as behaving ethically if its operations pay attention to all interests of stakeholders. The second theory is the Integrative Contract Social Theory which is prosed by Donaldson \& Dunfee (1994). This theory assumes that there is a social contract that creates ethical obligations for the company. The social contract is divided into two-levels, which are macrosocial which includes all rational contractors, and microsocial that includes the company's contract with a member from specific communities, such as departments within the company, professional organizations, industries, etc. Integrative Social Contract Theory combines contracts from macrosocial and microsocial as one social contract. Companies are considered to behave ethically if they operate in accordance with the social contract. The integrated social contract acts as a corridor for the company to undertake their social responsibility activities so that the corporate social responsibility does not only fulfill social contracts with certain parties but with all parties. This will lead to encouragement in ethical behavior in every part of the company.

The philosophy that underlies ethical perspective is utilitarianism popularized by a philosopher called Jeremy Bentham (1748-1832) who stated that the best action is one that maximized utility. The utility is defined as living creatures that have emotions, which are humans. The utility is the number of actions taken to creates happiness minus the suffering resulted from the actions. Companies will choose an action from several available alternatives to maximize the welfare of most parties interested in the company. Apart from utilitarianism, another philosophy that underlies ethical perspective is virtue ethics popularized by Aristoteles (348-322 BC) in the west and Confucious (551-479 BC) in the east. Virtue ethics emphasizes virtue or moral character instead of the consequences of an action. In virtue ethics, a good action is chosen because it is the virtue of the moral character of the person who does the action and not acting it to receive better consequences from the action. In the Confucious teaching, virtue ethics is called "ren" or people who have excellent ethics and morals. This shows that ethical behavior is a manifestation of the value owned and not as an action taken to obtain certain benefits.

\section{NATURALISTIC FALLACY IN CORPORATE SOCIAL RESPONSIBILITY PRACTICES}

The problem that arises is when corporate social responsibility is only seen as a marketing tool in achieving company goals. Corporate social responsibility is an interesting issue because it is a trend and focus of stakeholders amidst environmental problems facing the world today, such as global warming, and social problems such as poverty and health. The company is positioned as the party responsible for these 
problems and the company's ability to play an active role in overcoming them through social responsibility programs will create a reputation as a good company which in turn will lead to an increase in the company's financial performance. Maden et al. (2012) found that corporate social responsibility as an antecedent has a positive effect on company reputation and company reputation has a positive effect on customer, employee, and investor behavior.

This condition creates what is known as the naturalistic fallacy. The terminology was put forward by the British philosopher George Edward Moore in 1903 in his book Principia Ethica. According to Moore (1993), the naturalistic fallacy arises when the terms 'pleasant' or 'desirable' are defined as 'good'. Or in other words, a good thing means something pleasant or desirable. This means that if humans can do things that are pleasant or wanted, then that person has done a good thing. Moore stated that goodness is of a higher quality than pleasing or desirable and so good cannot be equated with what is pleasing or desirable. A naturalistic error occurs when the words good and pleasant describe the same object so that they are considered to have the same quality attributes. Moore (1933) further provides an example if we want to understand the color yellow then we must look at examples of yellow. Understanding yellow is not enough just reading a dictionary and understanding that yellow is the color in the middle of an egg or lemon that is peeled or yellow is the name for the color between green and orange. All of these things are yellow and yellow is more than just these things.

The naturalistic fallacy in social responsibility occurs when stakeholders and society think the company has behaved ethically if the company is active in social responsibility. This is used by the manager who opportunistic to undertake social responsibility only for economic purposes. Fritzche (1991) states that categorized company activities can become window dressing when associated with personal interests and organizational egoism. Furthermore, Hemmingway \& Halagan (2004) and Prior et.al (2008) stated that companies carry out social responsibility activities as a means of covering up or disguising fraud by companies so that the company's performance looks good. Companies can also conduct and report social responsibility activities to give the impression that the company is transparent even though the company carries out fraudulent practices such as earnings management and tax avoidance. Managers will try to carry out corporate social responsibility activities as a strategy to divert the attention of stakeholders to the manager's opportunistic behavior. This condition can cause corporate social responsibility activities to only become a corporate image tool as a mechanism to hide earnings management and tax avoidance practices. Besides, corporate social responsibility practices can also be used to neutralize or restore stakeholder confidence in the company's negative conditions. Ling and Sultana (2013) using a sample of companies in Singapore found that companies with high stock volatility tended to disclose more social responsibility, especially in the fields of environment, energy, human resources, products, and consumers. This is done to provide a good image and maintain shareholder trust. On the taxation side, Preus (2010) finds companies that are active in tax avoidance activities by moving their head office locations to tax haven countries claiming that they are actively involved in social responsibility activities. This condition is increasingly seen in developing countries that still have weak law enforcement and oversight. Muttakin et al. (2015) found a positive relationship between earnings management activities and the level of corporate social responsibility disclosure. This means that social responsibility becomes a means of shifting issues for managers so that their profit management actions are not known by stakeholders.

The naturalistic fallacy also occurs in measuring the company's business ethics performance. Spiller (2000) developed a model for measuring the ethical performance of companies using the Ethical Performance Scorecard (EPS) based on stakeholder theory. This model links aspects of corporate social responsibility with stakeholder groups, namely the community, environment, employees, customers, suppliers, and shareholders. The spiller then determines the key points for each of these stakeholder groups. The company is then assessed based on its social responsibility ability to fulfill these points. The higher the points that are fulfilled, the higher the EPS value of the company which means the company has high ethical behavior. However, in these points, there is no single aspect of the quality of the financial statements that are used as a measure to assess a company's ethical performance. This model assumes that companies that actively carry out social responsibility are ethical in their business practices.

Companies that are active in social responsibility activities do not necessarily have the same attributes as ethical behavior. The credibility of a company as an ethical company cannot be measured by how active the company performs and expresses its social responsibility. Being active in social responsibility activities is part of ethical behavior, but ethical behavior has a higher quality than just actively engaging in social responsibility activities. This ethical behavior is not only manifested by actively contributing to society but also this behavior is reflected in the company's operational activities. Goel (2010) states that one of the main characteristics of the triple bottom line concept is transparency regarding the company's financial condition. 
Meanwhile, Atkins (2006) states that what is meant by the public as a company that has social responsibility is a company that carries out transparency in financial reporting. Companies that behave ethically in implementing social responsibility practices to meet the expectations of stakeholders should also behave ethically in financial reporting because corporate financial reporting itself is part of corporate social responsibility. Ethical behavior must underlie corporate social responsibility and the concept of corporate social responsibility should not only focus on environmental, social, and economic issues but also on aspects of corporate financial reporting. Companies that are active in social responsibility should also have better quality earnings (Kim et al. 2012, Bozzolan et al., 2013)

Besides, the problem of naturalistic fallacy causes the implementation of social responsibility activities to be not optimal. Karnani (2010) states that if profit and social prosperity are not compatible, then investment in social responsibility activities is considered ineffective. Companies will choose social activities that are low cost and/or potential for profit. Social responsibility activities will be selected based on the greatest benefits that can be contributed to these activities to the company's profits. Decision-making is based on what social responsibility activities the community likes or wants which does not necessarily contribute greatly to the community itself. For example, the activities carried out are more for physical assistance such as buildings or other assets rather than assistance that is economic empowerment such as training and business assistance because physical assistance is more ' tangible ' and the results are faster than non-physical assistance that is needed relatively longer time to see results. This makes social responsibility activities more partial and monumental than comprehensive and sustainable, which are the main focus of social responsibility activities.

\section{CONCLUSION}

The presence of social responsibility practices has become an important issue in the business world that requires careful interpretation. Companies that actively disclose their social responsibility practices do not necessarily recognize as companies that behave ethically in their overall business practices. The paradox that occurs shows that social responsibility is not only based on the company's ethical behavior but also based on the manager's opportunistic behavior to gain or bring benefits to certain parties. The paradox in social responsibility is an important part that needs to be explained by the educator so that it provides a careful and comprehensive understanding. In addition, this condition also shows that information on social responsibility disclosure cannot be the main information in decision making but must be followed by other information, namely financial statements which are part of corporate social responsibility. This is because corporate social responsibility covers all aspects of the company. Research on corporate social responsibility does not only focus on its relationship with short-term performance but more importantly on companies' motivation and behavior in disclosing their long-term social responsibility. This study is of interest, especially in developing countries where they have low awareness and law enforcement towards practices related to corporate social responsibility.

\section{REFERENCE LIST}

Arli, D., dan Tjiptono, F. 2014. Does Corporate Social Responsibility Matter to Consumers in Indonesia? Social Responsibility Journal 10 (3), 537-549.

Atkins, B. 2006. Corporate Social Responsibility: Is It "Irresponsibility"? The Corporate Governance Advisor 14 (6): 28-29.

Barney, Jay. 1991. Firm Resources and Sustained Competitive Advantage. Journal of Management 17 (1): 99-120

Blazovich, J., dan Smith, L. M. 2010. Ethical Corporate Citizenship: Does it Pay? SSRN Working Paper Series.

Bozzolan, S., M. Fabrizi, C.A. Mallin, dan G. Michelon. 2015. Corporate Social Responsibility and Earnings Quality: International Evidence. The International journal of Accounting 50 (2015): 361-396.

Bowen, H.R. 1953. Social Responsibilities of the Businessman. New York: Harper \& Row.

Carroll, A.B. 1979. A Three-Dimensional Conceptual Model of Corporate Performance. Academy of Management Review 4 (4), 497-505.

Donaldson, T. Dan T.W. Dunfee. 1994. Toward A Unified Conception of Business Ethic: Integrative Social 
Contract Theory. Academy of Management Review 19 (2): 252-284.

Freeman, R. E. 1984. Strategic Management: A Stakeholder Approach. Massachusetts: Pitman Publishing Inc.

Friedman, Milton. 2002. Capitalism and Freedom, 40 anniversary edition. Chicago: The University of Chicago Press Chicago and London

Fritzsche, D. J. 1991. A Model of Decision Making Incorporating Ethical Values. Journal of Business Ethics $10(11): 841-852$.

Goel, P. 2010. Triple Bottom Line Reporting: An analytical Approach for Corporate Sustainability. Journal of Finance, Accounting and Management 1 (1): 27-42.

Grougiou, V., E. Dedoulis, dan S. Leventis. 2016. Corporate Social Responsibility Reporting and Organizational Stigma: The Case of "Sin" Industries. Journal of Business Research 69 (2): 905-914

Harjoto, M. A., dan Jo, H. 2011. Corporate Governance and CSR Nexus. Journal of Business Ethics 100 (1): 45-67.

Hemingway, C., dan Maclagan, P. 2004. Managers' Personal Values as Drivers of Corporate Social Responsibility. Journal of Business Ethics 50 (1): 33-44.

Holder-Webb, L., Cohen, J., Nath, L., dan Wood, D. 2009. The supply of corporate social responsibility disclosures among U.S. firms. Journal of Business Ethics, 84(4), 497-527.

Hong, Y, dan M.L. Andersen. The Relationship Between Corporate Social Responsibility and Earnings Management: An Explanatory Study. Journal of Business Ethics 104 (4): 461-471.

Juscius, V. and Kondratyuk, N. 2012. "Marketing Corporate Social Responsi-bility in Alcohol Industry". Economics and Management, 17, (1): 328-334.

Karnani, A. 2010. The Case Aganist Corporate Social Responsibility. Wall Street Journal, online .

Kim, Y., Park, M. S., dan Wier, B. 2012. Is Earnings Quality Associated with Corporate Social Responsibility? The Accounting Review 87 (3): 761-796.

Lev, B., Petrovits, C., Radhakhrisnan, S. 2010. Is Doing Good Good for You? How Corporate Charitable Contributions Enhance Revenue Growth. Strategic Management Journal 31: $182-200$.

Ling, T. C., dan Sultana, N. 2015. Corporate Social Responsibility: What Motivates Management to Disclose?. Social Responsibility Journal 11 (3), 513-534.

Maden, C., Arikan, E., Telci, E. E., Kantur, D. 2012. Linking Corporate Social Responsibility to Corporate Reputation: A Study on Understanding Behavioral Consequences. Procedia - Sosial and Behavioral Sciences 58 (2012): 655-664.

Mahadeo, J. D., Oogarah-Hanuman, V., dan Soobaroyen, T., 2011. A Longitudinal Study of Corporate Social Disclosures in A Developing Economy. Journal of Business Ethics 104 (4), 545-558.

McKinsey. 2010. How Companies Manage Sustainability: McKinsey Global Survey Results.

Moore, G.E. 1933. Principia Ethica, revised edition. Cambridge University Press.

Moura-Leite, R. S., dan Padgett, R. C., 2011, Historical background of corporate social responsibility, Social Responsibility Journal, 7(4), 528-639.

Muttakin, M. B., Khan, A., dan Azim, M. I. 2015. Corporate Social Responsibility Disclosure and Earnings Quality, Are they A Reflection of managers' opportunistic behavior? Managerial Auditing Journal 30 (3), 277-298.

Orlitzky, M., Schmidt, F. dan Rynes, S. 2003. Corporate Social and Financial Performance: a meta-analysis. Organizational Studies 24: 403-441.

Preuss, L. 2010. Tax Avoidance and Corporate Social Responsibility: You Can't Do Both, or Can You? Corporate Govenance 10 (4), 365-374.

Prior, D., J. Surroca, dan J.A. Tribo. 2008. Are socially Responsible Manager Really Ethical? Exploring the Relationship Between Earnings Management and Corporate Social Responsibility. Corporate Governance 16 (3): 160-177. 
Ross, Stephen A. 1977. The Determination of Financial Structure: The Incentive-Signalling Approach. The Bell Journal of Economics 8 (1): 23-40.

Scholtens, Bert dan Feng-Ching Kang. 2012. Corporate Social Responsibility and Earnings Management: Evidence form Asian Economies. Corporate Social Responsibility and Enviromental Management 20 (2): 95-112.

Spence, Michael. 1973. Job Market Signaling. The Quarterly Journal of Economics 87 (3): 355-374.

Spiller, R. 2000. Ethical Business and Investment: A Model for Business and Society. Journal of Business Ethics 27 (1/2): 149-160.

Tanjaya, F. dan E.B. Santoso. 2016. Hubungan Corporate Social Responsibility (CSR) dan Marketing terhadap Kinerja Keuangan Perusahaan. Jurnal Riset Akuntansi dan Keuangan 12 (1): 21-33.

Thornton, G. 2008. Corporate Social Responsibility: A necessity not a choice, International Business Report. Grant Thornton.

Wang, Y. G. 2011. Corporate Social Responsibility and Stock Performance - Evidence from Taiwan. Modern Economy 2 (5): 788-799.

Wernerfelt, Birger. 1984. A Resource-Based View of the Firm. Strategic Management Journal 5 (2): 171-180

World Business Council for Sustainability Development. 2000. Corporate Social Responsibility: Making Good Business Sense. 